\title{
KONCEPCJA PIENIACDZA MIĘDZYNARODOWEGO W WARUNKACH GLOBALNEGO KRYZYSU FINANSOWEGO
}

\section{WSTĘP}

Kryzys finansowy, który rozpoczął się w następstwie załamania na amerykańskim rynku nieruchomości jesienią 2007 roku, podważył zaufanie do dolara, jako jednostki pełniącej funkcję pieniądza międzynarodowego. Inwestycje w amerykańskie papiery skarbowe zaczęto postrzegać jako mniej bezpieczne niż do tej pory. Silne wahania kursu dolara sprawiły, że oficjalni i prywatni wierzyciele USA zaczęli się obawiać o przyszłą wartość utrzymywanych przez siebie rezerw, gromadzonych w aktywach dolarowych.

W tej sytuacji nie dziwi, że coraz więcej krajów otwarcie wyraża chęć ograniczenia hegemonii dolara w międzynarodowych stosunkach walutowych. Pierwszym krokiem, służącym osiągnięciu tego celu, ma być ograniczenie udziału dolara w oficjalnych rezerwach walutowych krajów członkowskich MFW. Do takiego kroku wezwali przedstawiciele Chin, Rosji i Indii. Prezydent Rosji ogłosił, że system walutowy oparty na dolarze jest „wadliwy”, a Centralny Bank Rosji ograniczył udział aktywów dolarowych w oficjalnych rezerwach walutowych ${ }^{1}$. Natomiast prezes Ludowego Banku Chin sformułował apel o stworzenie nowej międzynarodowej jednostki rezerwowej bądź też o nadanie takiego statusu już istniejącej jednostce Międzynarodowego Funduszu Walutowego - Specjalnym Prawom Ciągnienia ${ }^{2}$.

Ciekawość budzi, czy i w jakim stopniu urzeczywistnienie tych zamierzeń jest możliwe oraz czy ich realizacja może doprowadzić do utworzenia nowego pieniądza międzynarodowego. Biorąc to pod uwagę, w artykule przyjęto nastę-

${ }^{1}$ The dollar's role as the world's main reserve currency is being challenged, „The Economist”, 9 lipca 2009, http://www.economist.com/businessfinance/displaystory.cfm?story_id=13988512.

${ }^{2}$ Z. Xiaochuan, Reform the international monetary system, „BIS Review” 2009, no. 41, s. 1-3. 
pujące cele badawcze: 1) określenie, czy możliwe jest nadanie SDR - jednostce obrachunkowej MFW - statusu głównej waluty rezerwowej, oraz 2) określenie, czy możliwy jest spadek udziału dolara w oficjalnych rezerwach walutowych na rzecz innej jednostki pieniężnej.

Realizacji celu badawczego podporządkowano strukturę opracowania. W części drugiej syntetycznie przedstawiono pojęcie pieniądza międzynarodowego. Część trzecią poświęcono wyjaśnieniu, czym jest SDR i dlaczego jednostka ta nie pełniła dotąd funkcji pieniądza międzynarodowego. W części czwartej zbadano strukturę oficjalnych rezerw walutowych krajów członkowskich MFW. Część piąta przybliża propozycję, która miałaby prowadzić do zmian tej struktury, a także uwarunkowania jej realizacji.

\section{PIENIĄDZ MIĘDZYNARODOWY I JEGO FUNKCJE}

Współczesny pieniądz fiducjarny jest miernikiem wartości w znaczeniu miernika ogólnej siły nabywczej. Aby jednak dana jednostka mogła być potraktowana jako pieniądz, musi być także wyposażona w walutę, czyli w zdolność bezwarunkowego zwalniania od zobowiązań. Dzięki temu jednostka pieniężna może służyć jako prawny środek płatniczy. Połączenie tych dwóch cech nadaje danej jednostce atrybut pieniądza, będącego jednocześnie prawnym środkiem płatniczym, miernikiem wartości i jednostką obrachunkową. Gdy jednostka ma zdolność wypełniania tych funkcji nie tylko w kraju lub w grupie integrujących się krajów, ale także na całym świecie, wówczas zyskuje status pieniądza międzynarodowego.

Pieniądz międzynarodowy służy więc do porównywania jednostek pieniężnych poszczególnych krajów i określaniu kursów walutowych, a także do porównywania należności i zobowiązań, będących rezultatem wymiany handlowej między krajami. Wykorzystuje się go też do przeprowadzania rozliczeń zagranicznych - służy wtedy jako powszechnie akceptowany środek płatniczy, czyli numéraire.

Pieniądz międzynarodowy winien również pełnić funkcję rezerwową ${ }^{3}$ Trzeba podkreślić, że funkcja ta jest jednak jedynie pochodną funkcji numéraire - jednostka, która jest środkiem płatniczym w skali międzynarodowej, będzie utrzymywana jako składnik rezerw walutowych właśnie po to, by móc nią dokonywać płatności w przyszłości.

Zdaniem P. De Grauwe i G. S Tavlasa, by międzynarodowa jednostka pieniężna mogła pełnić przedstawione funkcje, emitent musi zapewnić stałą i możliwą do przewidzenia w przyszłości wartość tej jednostki. Wymaga to spełnienia

${ }^{3}$ R. I. McKinnon, The Rules of the Game: International Money in Historical Perspective, "Journal of Economic Literature” 1993, no. 3, s. 27. 
dwóch warunków. Emitent musi zobowiązać się do utrzymywania stałej wartości jednostki pieniężnej oraz zapewnić jej wymienialnośćc. Można więc stwierdzić, że utrzymywanie stałej wartości międzynarodowej jednostki pieniężnej ma dać jej posiadaczom pewność przyszłej wartości. Natomiast zapewnienie przez emitenta wymienialności tej jednostki ma zagwarantować jej doskonałą obiegowość. Pieniądz międzynarodowy musi więc cechować się płynnością 5 . Spełnienie tego wymogu jest jednak bardzo trudne. W praktyce, o ile zapewnienie wymienialności jednostki pieniężnej - a przez to doskonałej obiegowości - nie stanowi problemu, to już zagwarantowanie jej stabilnej wartości jest bardzo trudne.

Można twierdzić, że stabilność tę łatwiej osiągnąć, gdy pieniądz międzynarodowy jest emitowany przez międzynarodową instytucję finansową, która dostosowuje jego kreację do potrzeb krajów, które zrzesza. Gdy jednak nie ma pieniądza tworzonego przez taką instytucję, powstaje zjawisko konkurencji walutowej ${ }^{6}$. Może się wówczas zdarzyć, że żadna jednostka pieniężna nie będzie wystarczająco płynna, by móc w sposób sprawny pełnić funkcję numéraire i miernika wartości. Następuje wtedy ich rozszczepienie pomiędzy różne jednostki. Mogą być nimi jednostki pieniądza wspólnego, emitowane przez grupę integrujących się krajów, lub narodowe jednostki pieniężne najsilniejszych państw świata.

Taki właśnie stan ukształtował się w latach siedemdziesiątych ubiegłego wie$\mathrm{ku}, \mathrm{z}$ chwilą upadku systemu z Bretton Woods, i trwa do dziś. Mimo że istnieje jednostka SDR, emitowana przez Międzynarodowy Fundusz Walutowy, nie pełni ona funkcji pieniądza międzynarodowego. W pewnym stopniu pełnią ją natomiast tzw. waluty swobodnie używane - dolar amerykański, funt szterling, jen japoński i euro ${ }^{7}$.

\section{CZYM JEST, A CZYM NIE JEST SDR?}

${ }^{4}$ Por. m.in.: P. De Grauwe, International Money. Postwar Trends and Theories, $2^{\text {nd }}$ edition, Oxford University Press, Oxford 1996, s. 9; G. S. Tavlas, The International Use of Currencies: The U.S. Dollar and the Euro, „Finance \& Development” 1998, no. 2, http:/www.imf.org/external/pubs/ft/ fandd/1998/06/index.htm.

${ }^{5}$ Jak wynika z literatury, przez płynność pieniądza można właśnie rozumieć stop pewności przyszłej wartości i doskonałej obiegowości (J. Robinson, Akumulacja kapitatu, PWN, Warszawa 1958, s. 51-52).

${ }^{6}$ B. J. Cohen, The Future of Money, Princeton University Press, Princeton-Oxford 2004, s. $36-37$.

${ }^{7}$ Jednostki pieniężne krajów, które uzyskały taki status, można bez ograniczeń używać w rozliczeniach z tytułu obrotów bieżących, w obrotach kapitałowych, a także w płatnościach na rzecz MFW. W dniu 31 marca 1978 r. status walut swobodnie używanych otrzymało 5 walut: dolar amerykański, funt brytyjski, frank francuski, marka niemiecka i jen japoński (IMF, Selected Decisions of the International Monetary Fund and Selected Documents, wyd. 10, Waszyngton 1983, s. 301). Dwadzieścia lat później, 17 grudnia 1998 r., status taki zyskało euro. Utraciły go marka niemiecka i frank francuski (European Economic and Monetary Union and the IMF, [w:] IMF, Annual Report 1999, Waszyngton 1999, s. 172). 
Prace nad kreacją jednostki Specjalnych Praw Ciągnienia rozpoczęto już w 1963 roku. Początkowo jednak nie było zgodności, jakie funkcje ma ona pełnić oraz w jaki sposób ją emitować ${ }^{8}$. Propozycję emisji SDR jako międzynarodowej jednostki zaakceptowano ostatecznie we wrześniu 1967 roku na corocznym spotkaniu członków MFW w Rio de Janeiro, gdzie przyjęto studium jej poświęcone 9 . Zmianę statutu, która umożliwiła tę emisję, wprowadzono 28 lipca 1969 roku. Ratyfikowało ją 104 członków MFW ${ }^{10}$.

Nazwa SDR pochodzi od pierwszych liter oznaczających metodę tworzenia tej jednostki, a mianowicie od Special Drawing Rights, czyli specjalnych praw ciągnienia. Suma emisji SDR stała się składnikiem oficjalnych rezerw walutowych. Początkowo jednostki SDR miały parytet złota równy 0,888671 g czystego złota. Taki sam parytet miał dolar, stąd też w literaturze SDR nazywano papierowym złotem ${ }^{11}$.

Wypada podkreślić, że ratyfikując zmiany statutu, kraje członkowskie, które wyraziły taką wolę, stały się uczestnikami rachunku SDR prowadzonego w MFW. Uczestnicy tego rachunku otrzymali przydział tego pieniądza proporcjonalnie do udziałów w Funduszu i zobowiązali się, że będą posługiwali się nim jako środkiem płatniczym. Do jednostki SDR przylgnęło wówczas określenie numéraire zaproponowane przez L. Walrasa, a oznaczające pieniądz abstrakcyjny, powszechnie akceptowany środek płatniczy.

Operację kreacji SDR nazwano alokacją ${ }^{12}$. Pierwsza alokacja nastąpiła 1 stycznia 1970 roku. Emitowano wtedy pierwszą transzę SDR - w sumie 3,414 mld. W latach 1970-1972 dokonano alokacji trzech transz na sumę 9,4 mld SDR. Druga alokacja nastąpiła w latach 1979-1981 na łączną sumę 12 mld SDR. Razem emitowano więc 21,4 mld SDR.

SDR emitowano w postaci bezgotówkowej. Przyjęto, że będzie się można posługiwać tą jednostką, by kupić od Funduszu waluty obce niezbędne dla dokona-

${ }^{8}$ Por m.in.: G. Bird, The Political Economy of the SDR: The Rise and Fall of an International Reserve Asset, [w:] G. Bird, D. Rowlands (red.), The International Monetary Fund and the World Economy, t. 2, The International Library of Critical Writings in Economics, nr 208, Edward Elgar, Cheltenham-Northampton 2007, s. 484; Long Negotiations to Establish the SDR Overcame Deep Divisions In Viewpoints, IMF Survey z 18 kwietnia 1977, s. 114-115.

${ }^{9} \mathrm{~J}$. Gold, The Next Stage in the Development of International Monetary Law: The Deliberate Control of Liquidity, „The American Journal of International Law” 1968, no. 2, s. 365-402.

${ }^{10}$ Z. Knakiewicz, Nowa międzynarodowa jednostka walutowa "Prawo Specjalnego Ciagnienia” Międzynarodowego Funduszu Walutowego, „Ruch Prawniczy, Ekonomiczny i Socjologiczny” 1971, z. 1, s. 231.

${ }^{11}$ J. M. Boughton, Silent Revolution, The International Monetary Fund 1979-1989, IMF, Waszyngton 2001, s. 924.

${ }_{12}$ Chronology. IMF adapts and expands operations to meet member's countries changing needs, „IMF Survey Supplement” 2000, no. 29, s. 28. 
nia zapłat zagranicznych, zapadających z różnych tytułów. Jednostki SDR można było również wykorzystać, by odkupić zasoby waluty własnej, utrzymywane przez inne kraje członkowskie. Musiał jednak wyrazić na to zgodę kraj wierzycielski ${ }^{13}$.

Odejście od systemu par values $\mathrm{w}$ wyniku załamania się systemu z Bretton Woods przyczyniło się do wprowadzenia nowych zasad ustalania kursu jednostki SDR. I tak, 1 lipca 1974 roku zaczęto ustalać wartości tej jednostki za pomocą zmian kursów 16 walut wchodzących w skład koszyka walutowego ${ }^{14}$. W 1981 roku zredukowano ich liczbę do 5 walut swobodnie używanych, a w 1998 roku w konsekwencji zastąpienia marki niemieckiej i franka francuskiego przez euro - do czterech ${ }^{15}$. Charakterystyczne jest, że gdy odrzucono parytet złota SDR ${ }^{16}$, nastąpiło po raz pierwszy formalne oderwanie pieniądza od złota. SDR stał się pierwszą jednostką, która nie była powiązana z tym kruszcem.

Dzięki przyjętemu sposobowi wyceny SDR należał i wciąż należy do najbardziej stabilnych jednostek pieniężnych na świecie. Mimo tego, jednostka SDR stopniowo ulegała marginalizacji ${ }^{17}$. Niewątpliwie wpłynęło na to fiasko projektu przekształcenia części sald dolarowych krajów członkowskich MFW w salda $\mathrm{SDR}^{18}$, a także brak realizacji uchwały przyjętej na spotkaniu w dniach 7-8 stycznia 1976 roku w Kingston na Jamajce, zgodnie, którą jednostka SDR miała stać się głównym składnikiem oficjalnych rezerw walutowych ${ }^{19}$. Upowszechnienie jednostki SDR jako środka płatniczego utrudniały także bardzo restrykcyjne warunki dotyczące emisji $\mathrm{SDR}^{20}$.

Sprawiło to, że w latach 1981-2009 w ogóle nie dokonywano alokacji SDR, i to mimo podjęcia we wrześniu 1997 roku uchwały, która miała umożliwić dokonanie specjalnej, jednorazowej alokacji SDR w wysokości 21,4 mld, a także

${ }^{13}$ How SDRs Are Created and Values And How Their Possible Uses Are To Be Broadened by Amendment, „IMF Survey Supplement” 1976, s. 5-6.

${ }^{14}$ Do koszyka walut weszły waluty tych krajów, których przeciętny udział w światowym eksporcie towarów i usług był w latach 1968-1972 wyższy niż 1\%. Ustalone wagi dla każdej waluty uwzględniały proporcje zależne od udziału w eksporcie. Stosowano także uznaniowe korekty (D. S. Cutler, Basket Valuation of SDR Takes Effect, IMF Survey z 8 lipca 1974, s. 209 i 213$-214)$.

${ }^{15}$ IMF, By-Laws Rules and Regulations, wyd. 60, Waszyngton, maj 2006, s. 51.

${ }^{16}$ Basket of 16 Currencies Fixed For SDR Valuation, IMF Survey z 17 czerwca 1974, s. 177 i 185 .

${ }^{17}$ H. James, International Monetary Cooperation Since Bretton Woods, IMF i Oxford University Press, Waszyngton i inne 1996, s. 270.

${ }^{18}$ P. B. Kenen, The Costs And Benefits of the Dollar As a Reserve Currency. Convertibility and Consolidation: A Survey of Options for Reform, „The American Economic Review” 1973, no. 2, s. 194.

${ }^{19}$ From the End of the Bretton Woods System to the Jamaica Agreement. A Chronology of Key Events in Changing World Financial Agreements in 1971-76, IMF Survey z dnia 1 marca 1976, s. 75.

${ }^{20}$ IMF, Articles of Agreement, Waszyngton 2004, s. 40-41. 
wprowadzić zmianę statutu MFW, ułatwiającą alokację SDR w przyszłości ${ }^{21}$. Chodziło głównie o udostępnienie jednostek SDR tym krajom, które przystąpiły do Funduszu po dokonaniu drugiej i ostatniej alokacji SDR, zakończonej w 1981 roku $^{22}$. Planom tym sprzeciwily się jednak Stany Zjednoczone ${ }^{23}$.

Przeszkody te spowodowały, że jednostka SDR nie mogła pełnić w sposób skuteczny funkcji pieniądza międzynarodowego ${ }^{24}$. Pozostała jedynie jednostką obrachunkową MFW. Podkreślono to w Raporcie rocznym MFW z 2007 roku ,stwierdzając, że jednostki SDR „nie są pieniądzem, ani wierzytelnością wobec MFW, a mogą jedynie służyć pozyskaniu walut swobodnie używanych"25.

Sytuacja ta uległa zmianie wskutek szczytu grupy G 20 w Londynie, który odbył się 2 kwietnia 2009 roku. Na szczycie tym liderzy grupy G 20 zaproponowali specjalny pakiet działań mających wspomóc odbudowę gospodarczą. Wezwali w nim m.in. do szybkiej ratyfikacji czwartego rozszerzenia statutu MFW, umożliwiającej dokonanie alokacji SDR zgodnie $\mathrm{z}$ rozdzielnikiem przewidzianym w $1997 \mathrm{roku}^{26}$. Biorąc to pod uwagę, USA zmienily stanowisko w sprawie czwartego rozszerzenia statutu MFW. Pakiet ustaw umożliwiający jego ratyfikację został ostatecznie przyjęty przez Kongres USA w czerwcu 2009 roku $^{27}$. Dzięki temu czwarte rozszerzenie statutu MFW weszło w życie 10 sierpnia 2009 roku, kiedy to oficjalnie potwierdzono jego ratyfikację przez wymaganą większość 112 członków, dysponujących ponad 85\% głosów na forum Funduszu. Przydział

${ }^{21} \mathrm{IMF}$, Annual Report 1999, Waszyngton, s. 108.

${ }^{22}$ SDR supplements existing reserves and constitutes IMF's unit of account, „IMF Survey Supplement" 2000, no. 29, s. 27.

${ }^{23}$ Do 30 czerwca 2009 r. 132 członków Funduszu dysponujących łącznie 77,7\% ogólnej liczby głosów zakończyło ratyfikację tej uchwały (Special Drawing Rights $Q \mathcal{E} A$, http://www.imf.org/ external/np/exr/faq/sdrallocfaqs.htm). Do osiągnięcia wymaganych $85 \%$ brakowało jednak zgody USA (J. J. Polak, P. B. Clark, International Liquidity and the Role of the SDR in the International Monetary System, [w:] J. M. Boughton (red.), Economic Theory and Financial Policy. Selected Essays of Jacques J. Polak 1994-2004, IMF-M.E. Sharpe, Londyn 2005, s. 181).

${ }^{24}$ Por. m.in.: B. Eichengreen, Global Imbalances and the Lessons of Bretton Woods, The Cairoli Lectures, The MIT Press, Londyn-Cambridge 2007, s. 10; C. J. Ingram, The Dollar and the International Monetary System: A Retrospective View, „Southern Economic Journal” 1974, no. 4, s. 533.

${ }^{25} \mathrm{IMF}$, Annual Report 2007, Waszyngton, s. 33.

${ }^{26}$ IMF Executive Board Backs US\$250 Billion SDR Allocation to Boost Global Liquidity, IMF Press Release 2009, no. 09/264, http://www.imf.org/external/np/sec/pr/2009/pr09264.htm; The Global Plan for Recovery and Reform: Communiqué from the Group of Twenty London Summit, 2 April 2009, [w:] Deutsche Bundesbank, Auszüge aus Presseartikeln 2009, nr 15, s. 7 i 9; Annex-Declaration on delivering resources through the international financial institutions, London summit, 2 April 2009, [w:] Deutsche Bundesbank, Auszüge aus Presseartikeln 2009, nr 15, s. 10.

${ }^{27}$ U.S. Congress Vote Marks Big Step For IMF Reform, Funding, IMF Survey online z 18 czerwca 2009, http://www.imf.org/external/pubs/ft/survey/so/2009/NEW061809A.htm. 
jednostek SDR na mocy czwartego rozszerzenia statutu MFW nastąpił we wrześniu $2009 \mathrm{roku}^{28}$.

Innym elementem pakietu reform przedłożonego na szczycie w Londynie jest przeprowadzenie nowej alokacji SDR w kwocie odpowiadającej 250 mld USD, z czego 40\% trafiło do krajów rozwiniętych i rozwijających się. Plan ten zaakceptował Komitet Walutowy i Finansowy rady gubernatorów MFW ${ }^{29}$, a także zarząd $\mathrm{MFW}^{30}$. Alokację przeprowadzono 28 sierpnia 2009 roku.

Wskutek nowych alokacji emisja SDR wzrosła ośmioipółkrotnie. Na SDR przypada dziś jednak zaledwie około 5\% światowych oficjalnych aktywów rezerwowych. Jednostki SDR w nikłym stopniu uzupełniają płynność międzynarodową. Ich kreacja nie jest dostosowana do rozwoju handlu światowego i wzrostu gospodarczego. Określanie jej mianem pieniądza międzynarodowego lub numéraire jest błędem. Funkcję tę pełnią waluty swobodnie używane. Ich kurs wobec innych walut odznacza się jednak wysoką i trudną do przewidzenia zmiennością. Pozostają więc one ułomnym miernikiem wartości.

\section{SKŁADNIKI OFICJALNYCH REZERW WALUTOWYCH KRAJÓW CZŁONKOWSKICH MFW}

By ocenić zakres wykorzystania narodowej jednostki pieniężnej w charakterze pieniądza międzynarodowego przez władze gospodarcze poszczególnych państw, zazwyczaj poddaje się ocenie jej zastosowanie w tzw. obrocie oficjalnym. Można przy tym przyjąć, że wyrazem pełnienia funkcji numéraire przez jednostkę pieniężną jest jej gromadzenie przez inne kraje w ich oficjalnych rezerwach walutowych.

Z tabeli 1 wynika, że w latach 1998-2007 udział dolara w sklasyfikowanych oficjalnych rezerwach walutowych wszystkich krajów MFW zawsze przekraczał 50\%, osiągając w 2001 roku szczytowy poziom w wysokości 71,5\%. Odwrócenie tendencji wzrostowej nastąpiło w 2002 roku. Było to sprzężone $\mathrm{z}$ widocznym wzrostem rezerw utrzymywanych w euro.

${ }^{28}$ IMF Governors Formally Approve US\$250 Billion General SDR Allocation, IMF Press Release 2009, no. 09/283, http://www.imf.org/external/np/sec/pr/2009/pr09283.htm.

${ }^{29}$ Communique of the International Monetary and Financial Committee of the Board of Governors of the International Monetary Fund, April 25, 2009, http://www.imf.org/external/np/cm/2009/042509. htm.

${ }^{30}$ IMF Executive Board Backs... 
Tabela 1. Struktura sklasyfikowanych oficjalnych rezerw walutowych krajów członkowskich MFW w latach 1998-2007, wg stanu na koniec roku

\begin{tabular}{|c|c|c|c|c|c|c|c|c|c|c|}
\hline WYSZCZEGÓLNIENIE & 1998 & 1999 & 2000 & 2001 & 2002 & 2003 & 2004 & 2005 & 2006 & 2007 \\
\hline \multicolumn{11}{|c|}{ wszystkie kraje członkowskie } \\
\hline Dolar USA & 69,4 & 71,0 & 71,1 & 71,5 & 67,1 & 65,9 & 65,9 & 66,9 & 65,5 & 63,93 \\
\hline Jen japoński & 6,2 & 6,4 & 6,1 & 5,0 & 4,4 & 3,9 & 3,8 & 3,6 & 3,1 & 2,9 \\
\hline Funt szterling & 2,7 & 2,9 & 2,8 & 2,7 & 2,8 & 2,8 & 3,4 & 3,6 & 4,4 & 4,7 \\
\hline Frank szwajcarski & 0,3 & 0,2 & 0,3 & 0,3 & 0,4 & 0,2 & 0,2 & 0,1 & 0,2 & 0,2 \\
\hline Euro & - & 17,9 & 18,3 & 19,2 & 23,8 & 25,2 & 24,8 & 24,1 & 25,1 & 26,5 \\
\hline Marka niemiecka & 13,8 & - & - & - & - & - & - & - & - & - \\
\hline Frank francuski & 1,6 & - & - & - & - & - & - & - & - & - \\
\hline ECU & 1,2 & - & - & - & - & - & - & - & - & - \\
\hline Pozostałe & 4,8 & 1,6 & 1,5 & 1,3 & 1,6 & 2,0 & 1,9 & 1,7 & 1,8 & 1,8 \\
\hline \multicolumn{11}{|c|}{ kraje wysokorozwinięte } \\
\hline Dolar USA & 67,3 & 73,0 & 72,3 & 72,2 & 68,2 & 69,8 & 70,9 & 73,0 & 71,3 & 69,4 \\
\hline Jen japoński & 6,8 & 6,6 & 6,3 & 5,5 & 4,3 & 3,8 & 3,5 & 3,4 & 3,5 & 3,1 \\
\hline Funt szterling & 2,1 & 2,2 & 2,1 & 2,0 & 2,2 & 1,6 & 2,0 & 2,2 & 2,6 & 2,8 \\
\hline Frank szwajcarski & 0,2 & 0,1 & 0,3 & 0,3 & 0,6 & 0,2 & 0,1 & 0,1 & 0,2 & 0,2 \\
\hline Euro & - & 16,5 & 17,4 & 18,4 & 23,0 & 22,6 & 21,4 & 19,6 & 21,0 & 23,1 \\
\hline Marka niemiecka & 13,7 & - & - & - & - & - & - & - & - & - \\
\hline Frank francuski & 1,2 & - & - & - & - & - & - & - & - & - \\
\hline $\mathrm{ECU}$ & 2,3 & - & - & - & - & - & - & - & - & - \\
\hline Pozostałe & 6,4 & 1,5 & 1,7 & 1,6 & 1,8 & 2,0 & 2,1 & 1,6 & 1,4 & 1,4 \\
\hline \multicolumn{11}{|c|}{ kraje rozwijające się } \\
\hline Dolar USA & 71,7 & 68,8 & 69,9 & 70,8 & 65,9 & 62,0 & 61,0 & 61,7 & 61,2 & 60,7 \\
\hline Jen japoński & 5,6 & 6,1 & 5,8 & 4,6 & 4,4 & 4,1 & 4,1 & 3,7 & 2,8 & 2,8 \\
\hline Funt szterling & 3,2 & 3,6 & 3,5 & 3,4 & 3,5 & 4,0 & 4,8 & 4,8 & 5,7 & 5,8 \\
\hline Frank szwajcarski & 0,5 & 0,4 & 0,3 & 0,2 & 0,2 & 0,2 & 0,2 & 0,2 & 0,1 & 0,1 \\
\hline Euro & - & 19,4 & 19,3 & 20,0 & 24,6 & 27,8 & 28,3 & 27,8 & 28,1 & 28,4 \\
\hline Marka niemiecka & 13,9 & - & - & - & - & - & - & - & - & - \\
\hline Frank francuski & 2,1 & - & - & - & - & - & - & - & - & - \\
\hline ECU & 0,0 & - & - & - & - & - & - & - & - & - \\
\hline Pozostałe & 2,9 & 1,7 & 1,3 & 1,0 & 1,3 & 2,0 & 1,6 & 1,8 & 2,1 & 2,1 \\
\hline
\end{tabular}

* Niedokładności wynikają z danych źródłowych. Tabela zawiera dane z tych krajów MFW, które zgłosiły skład utrzymywanych przez siebie oficjalnych rezerw walutowych.

Źródło: opracowanie własne na podstawie: IMF, Annual Report 2008, Appendix 1, International reserves, Waszyngton, s. 3. 
$\mathrm{Z}$ punktu widzenia struktury oficjalnych rezerw walutowych dolar ma jednak pozycję dominującą. Charakterystyczne jest też, że największy udział dolara w oficjalnych rezerwach walutowych mają kraje wysokorozwinięte, i to mimo że część z nich zmieniła w ostatnich latach strukturę oficjalnych rezerw walutowych na korzyść euro. I tak, w latach 2002-2008 udział dolara w oficjalnych rezerwach walutowych Szwajcarii spadł z 38\% na 28\%, w Wielkiej Brytanii zaś - z 32\% na 24\%. Podobne zjawisko wystąpiło w Kanadzie, gdzie udział ten spadł o 10 punktów procentowych, natomiast wzrósł udział euro i w lutym 2008 roku przewyższył 50\%. Tendencję wzrostu udziału euro w oficjalnych rezerwach walutowych można było zaobserwować również w Australii ${ }^{31}$. Dywersyfikację oficjalnych rezerw walutowych przeprowadzono także w Rosji. Władze tego kraju już w 2002 roku podniosły z $10 \%$ do $25 \%$ udział euro w oficjalnych rezerwach walutowych. Przedstawione postępowanie nie stało się jednak powszechne. Większość krajów uznała bowiem, że euro ma jedynie charakter pieniądza regionalnego i nie zagrozi pozycji dolara. Pogląd ten podzielono m.in. w Arabii Saudyjskiej i w państwach azjatyckich - Japonii, Tajwanie, Korei Południowej ${ }^{32}$. Na tę postawę nie wpłynął także wybuch światowego kryzysu finansowego. Potwierdzają to dane z tabeli 2.

Wynika z niej, że nominalna wartość oficjalnych rezerw walutowych utrzymywanych w dolarach bezpośrednio po wybuchu kryzysu w USA jesienią 2007 roku jeszcze wzrosła - i to o aż 300 mld USD - z ok. 2,5 bln USD w trzecim kwartale 2007 roku do ok. 2,8 bln USD w drugim kwartale 2008 roku. Wzrost ten umożliwił utrzymanie stabilnego udziału dolara w oficjalnych rezerwach walutowych krajów członkowskich MFW. W badanym okresie rozpiętość wahań tego udziału wyniosła bowiem zaledwie 2,5 punktu procentowego.

Widać więc wyraźnie, że - jak dotąd - sklasyfikowane oficjalne rezerwy walutowe nie podlegały znaczącym zmianom. Mimo prognoz recesji w USA, kraje członkowskie MFW nie zmieniły znacząco składu swoich rezerw oficjalnych. Struktura rezerw pozostała stabilna. Silne wahania kursu dolara sprawiły jednak, że zaczęto dostrzegać potrzebę ich dywersyfikacji.

${ }^{31} \mathrm{ECB}$, Review of the international role of the euro, grudzien 2003, Frankfurt n. Menem, s. 48; ECB, Review of the international role of the euro, styczen 2005, Frankfurt n. Menem, s. 54; ECB, Review of the international role of the euro, czerwiec 2007, Frankfurt n. Menem, s. 46; ECB, The international role of the euro, lipiec 2008, Frankfurt n. Menem, s. 48.

${ }^{32}$ J.-F. Ponsot, Dollarization and the Hegemonic Status of the US Dollar, [w:] L.-P. Rochon, S. Rossi (red.), Monetary and Exchange Rate Systems. A Global View on Financial Crises, Edward Elgar, Cheltenham-Northampton 2006, s. 24-25. 
Tabela 2. Struktura sklasyfikowanych oficjalnych rezerw walutowych krajów członkowskich MFW w okresie | 2007-| 2009

\begin{tabular}{|c|c|c|c|c|c|c|c|c|c|}
\hline \multirow{2}{*}{ WYSZCZEGÓLNIENIE } & \multicolumn{9}{|c|}{ OKRES } \\
\hline & I 2007 & II 2007 & III 2007 & IV 2007 & I 2008 & II 2008 & III 2008 & IV 2008 & 12009 \\
\hline \multicolumn{10}{|c|}{ w mld USD } \\
\hline $\begin{array}{l}\text { Oficjalne rezerwy } \\
\text { walutowe }\end{array}$ & 3511,68 & 3717,95 & 3895,28 & 4119,18 & 4382,12 & 4428,47 & 4360,07 & 4214,10 & 4057,90 \\
\hline \multicolumn{10}{|l|}{ Utrzymywane w: } \\
\hline Dolarach & 2294,76 & 2423,52 & 2499,59 & 2641,63 & 2768,80 & 2783,19 & 2808,88 & 2699,14 & 2636,26 \\
\hline Euro & 883,88 & 940,88 & 1018,40 & 1082,28 & 1169,37 & 1186,31 & 1117,01 & 1116,47 & 1050,76 \\
\hline Jenach japońskich & 101,43 & 102,72 & 104,49 & 120,47 & 136,57 & 147,72 & 139,29 & 136,17 & 118,07 \\
\hline $\begin{array}{l}\text { Funtach szterlin- } \\
\text { gach }\end{array}$ & 156,44 & 171,61 & 183,11 & 192,66 & 204,02 & 207,73 & 198,09 & 171,18 & 163,03 \\
\hline $\begin{array}{l}\text { Frankach szwajcar- } \\
\text { skich }\end{array}$ & 6,01 & 5,71 & 6,25 & 6,40 & 6,60 & 6,88 & 6,63 & 5,62 & 5,26 \\
\hline $\begin{array}{l}\text { Pozostałych walu- } \\
\text { tach }\end{array}$ & 69,16 & 73,51 & 83,45 & 75,73 & 96,76 & 96,66 & 90,17 & 85,25 & 84,53 \\
\hline \multicolumn{10}{|c|}{$\mathrm{w} \%$} \\
\hline $\begin{array}{l}\text { Oficjalne rezerwy } \\
\text { walutowe }\end{array}$ & 100,00 & 100,00 & 100,00 & 100,00 & 100,00 & 100,00 & 100,00 & 100,00 & 100,00 \\
\hline Utrzymywane w: & & & & & & & & & \\
\hline Dolarach & 65,35 & 65,18 & 64,17 & 64,13 & 63,18 & 62,85 & 64,42 & 64,05 & 64,97 \\
\hline Euro & 25,17 & 25,31 & 26,14 & 26,27 & 26,69 & 26,79 & 25,62 & 26,50 & 25,89 \\
\hline Jenach japońskich & 2,89 & 2,76 & 2,68 & 2,92 & 3,12 & 3,34 & 3,19 & 3,23 & 2,91 \\
\hline $\begin{array}{l}\text { Funtach szterlin- } \\
\text { gach }\end{array}$ & 4,45 & 4,62 & 4,70 & 4,68 & 4,66 & 4,69 & 4,54 & 4,06 & 4,02 \\
\hline $\begin{array}{l}\text { Frankach szwajcar- } \\
\text { skich }\end{array}$ & 0,17 & 0,15 & 0,16 & 0,16 & 0,15 & 0,16 & 0,15 & 0,13 & 0,13 \\
\hline $\begin{array}{l}\text { Pozostałych walu- } \\
\text { tach }\end{array}$ & 1,97 & 1,98 & 2,14 & 1,84 & 2,21 & 2,18 & 2,07 & 2,02 & 2,08 \\
\hline
\end{tabular}

Niedokładności o 0,1 wynikają z danych źródłowych. Dane za okres II 2008-I 2009 mają charakter wstępny.

Źródło: opracowanie własne na podstawie bazy danych IMF, Currency Composition of Official Foreign Exchange Reserves, http://www.imf.org/external/np/sta/cofer/eng/cofer.pdf, s. 1-2.

\section{PROPOZYCJA UTWORZENIA NOWEJ MIĘDZYNARODOWEJ WALUTY REZERWOWEJ I UWARUNKOWANIA JEJ REALIZACJI}

Głównym rysem propozycji, zasygnalizowanej we wstępie, a sformułowanej przez Z. Xiaochuana, prezesa banku centralnego Chin, jest dążenie do pogodzenia dwóch celów: dywersyfikacji oficjalnych rezerw walutowych i zmniejszenia ryzyka kursowego, którymi są one obciążone. W przypadku Chin jest to szczególnie ważne, zwłaszcza że przeważającą część rezerw walutowych i całej mię- 
dzynarodowej pozycji inwestycyjnej tego kraju stanowią aktywa dolarowe ${ }^{33}$. Ich przyszła wartość jest zagrożona. Amerykańska ekspansja fiskalna, która ma prowadzić do przezwyciężenia skutków kryzysu finansowego, może osłabić dolara, a w konsekwencji wywołać spadek wartości chińskich aktywów zagranicznych ${ }^{34}$. Biorąc to pod uwagę, Z. Xiaochuan zaproponował w swoim eseju, by ${ }^{35}$ :

- zastąpić dolara nową międzynarodową walutą rezerwową, którą miałaby się stać SDR;

- wykonać uchwałę w sprawie jednorazowej alokacji SDR, którą zarząd MFW przyjął w 1997 roku;

- rozszerzyć koszyk walut, na podstawie którego oblicza się codziennie kurs SDR, włączając do niego waluty najważniejszych gospodarczo państw świata;

- stworzyć fundusz w postaci puli rezerwowej SDR, dzięki któremu można by wymieniać aktywa nominowane w walutach swobodnie używanych na jednostki SDR;

- rozszerzyć pulę papierów wartościowych, nominowanych w SDR, ze szczególnym uwzględnieniem obligacji MFW;

- zezwolić na wykorzystywanie jednostek SDR nie tylko w transakcjach między bankami centralnymi krajów członkowskich i MFW, ale również w handlu międzynarodowym jako waluty fakturowania i rozliczania transakcji.

Według niego tylko w taki sposób można rozwiązać problem narastającej nierównowagi globalnej, której korzenie tkwią w wykorzystywaniu jednej z walut narodowych (dolara) jako pieniądza międzynarodowego. Uznał, że realizacja jego projektu wpłynie dodatnio na stabilizację cen aktywów finansowych. Pozwoli również zwiększyć płynność międzynarodową, łagodząc nierozstrzygalny $\mathrm{w}$ innych warunkach tzw. dylemat Triffina ${ }^{36}$. Propozycja ta zyskała poparcie części krajów rozwiniętych, jednak kraje wysokorozwinięte (m.in. USA) przyjęły ją $\mathrm{z}$ rezerwą.

${ }^{33}$ L. Barber, M. Wolf, J. Anderlini, K. Hille, Dollar backed as leading global currency, „Financial Times”, Frankfurt/London, June 2, 2009, [w:] Deutsche Bundesbank, Auszüge aus Presseartikeln 2009, nr 23, s. 19.

${ }^{34}$ Łączna wartość pakietu fiskalnego, który ma ożywić gospodarkę, a który został przyjęty w lutym tego roku przez prezydenta USA B. Obamę i Kongres USA, ma wynieść w latach fiskalnych 2009-2019 aż 787 mld USD (United States: 2009 Article IV Consultation - Staff Report; Staff Supplement; and Public Information Notice on the Executive Board Discussion, IMF Country Report 2009, no. 09/228, s. 20). W 2010 r. deficyt budżetowy w USA wyniesie aż 13\% - najwięcej od zakończenia II wojny światowej (J. E. Garten, America Still Rules, „Newsweek”, 3.08.2009, s. 30).

${ }^{35}$ Z. Xiaochuan, op. cit., s. 2-3.

${ }^{36}$ Ibidem. Zgodnie z tym dylematem, kraj, którego waluta jest wykorzystywana jako pieniądz międzynarodowy, nie może dbać o jej stabilny kurs i prowadzić restrykcyjnej polityki pieniężnej i fiskalnej, ponieważ ogranicza w ten sposób płynność międzynarodową pozostałych państw. 
Trzeba podkreślić, że propozycja zgłoszona przez Z. Xiaochuana nie stanowi novum. Postulaty takie zgłaszało wielu praktyków i ekonomistów. Listę tych ostatnich otwiera J. M. Keynes i jego propozycja wprowadzenia międzynarodowego pieniądza bankowego ${ }^{37}$, przekształcona później w projekt bankora, dyskutowany na konferencji w Bretton Woods i ostatecznie odrzucony ${ }^{38}$.Jednakże tym, co odróżnia propozycję Z. Xiaochuana od innych projektów, jest zarówno narodowość pomysłodawcy, jak i stanowisko, które piastuje. Trzeba bowiem pamiętać, że to właśnie Chiny utrzymują najwyższe na świecie oficjalne rezerwy walutowe ${ }^{39}$. Chiny są też najszybciej rozwijającym się rynkiem świata ${ }^{40}$. Sprawia to, że gospodarka światowa nie jest już zależna wyłącznie od sytuacji gospodarczej w USA, ale również od stanu chińskiej gospodarki ${ }^{41}$.

Warto zaznaczyć, że projekt gubernatora Ludowego Banku Chin został już częściowo zrealizowany, zrealizowano bowiem uchwałę z 1997 roku i przeprowadzono jednorazową, specjalną emisję SDR. Realizacja pozostałych elementów planu będzie jednak trudna. Emisja SDR jest bowiem zbyt mała, by wykorzystywać tę jednostkę w handlu międzynarodowym i by ograniczyć znaczenie dolara jako międzynarodowej waluty rezerwowej. Nie ma na razie zgody władz Funduszu, by rozszerzyć skład stosowanego od 1981 roku koszyka walut, na podstawie którego oblicza się kurs SDR, ani też by prowadzić emisję papierów wartościowych nominowanych w tej jednostce.

Charakterystyczne jest jednak, że Chiny jednostronnie podjęły już pewne działania, by osłabić znaczenie dolara. I tak, zwiększono zakres wymienialności juana. Mianowicie, od 6 lipca 2009 roku wybrane chińskie firmy z pięciu miast mogą posługiwać się chińskim juanem $\mathrm{w}$ transakcjach handlowych $\mathrm{z}$ przedsiębiorstwami pochodzącymi z Hongkongu, Makao i krajów grupy ASEAN. Zagraniczne banki mogą pożyczać juana od chińskich instytucji finansowych, by

${ }^{37}$ J. M. Keynes, A Treatise on Money. 2 The Applied Theory of Money, [w:] The Collected Writings of John Maynard Keynes, t. 6, The Macmillan Press Ltd.-Cambridge University Press, London $\mathrm{i}$ in. 1998, s. 358-361.

${ }^{38}$ Por. m.in.: J. M. Boughton, Why White, not Keynes? Inventing the Postwar International Monetary System, „IMF Working Papers” 2002, no. 52, s. 16-17; H. James, op. cit., s. 36-42.

${ }^{39}$ W latach 2003-2005 wartość oficjalnych rezerw walutowych Chin wzrosła dwukrotnie, z 412 mld USD do 826 mld USD. W 2006 r. ich wartość przekroczyła 1 bln USD. (Por. m.in.: China: more flexible exchange rate could assist monetary policy, IMF Survey 2006, no. 18, s. 285; To sustain rapid growth, China needs to rebalance its economy, IMF Survey 2006, no. 22, s. 350). Oficjalne rezerwy walutowe Chin stanowią ok. $1 / 3$ światowych rezerw.

${ }^{40}$ Zgodnie z prognozami MFW, chińska gospodarka ma się rozwijać w latach 2009-2010 w tempie 7,5\% i 8,5\%. W tym samym okresie tempo zmian produkcji USA wyniesie -2,6\% i 0,8\% (IMF, World Economic Outlook Update. An uptade of the key WEO projections, Waszyng ton, 8 lipca 2009, s. 2).

${ }^{41}$ R. Foroohar, China's Big Spender, „Newsweek”, 6-13.06.2009, s. 24. 
sfinansować ten handel ${ }^{42}$. Co więcej, Ludowy Bank Chin podpisał porozumienia swapowe na łączną sumę 95 mld USD z bankami centralnymi Argentyny, Białorusi, Hongkongu, Indonezji, Malezji i Korei Płd. Na ich mocy, gdy kraje te nie będą dysponować środkami do zapłaty za chiński import, wówczas będą mogły zaciągnąć krótkookresową pożyczkę w juanach ${ }^{43}$.

Oczywiście, te przedsięwzięcia nie są wystarczające, by ograniczyć dominację dolara. Są one raczej traktowane jako sygnał zmiany w polityce Chin, które z biernego obserwatora wydarzeń przekształcają się w aktywnego gracza, który chce współdecydować o zmianach światowej gospodarki ${ }^{44}$. Również propozycja prezesa banku centralnego Chin jest przejawem tego zjawiska. Wpisuje się ona przy tym w proces reform, które podjęto na forum MFW w reakcji na światowy kryzys finansowy.

Nasuwa się więc pytanie - czy rzeczywiście możliwe jest nadanie SDR statusu głównej waluty rezerwowej krajów członkowskich MFW? Czy też może inna jednostka pieniężna - np. euro - zakończy dominację dolara jako globalnej waluty rezerwowej i światowego numéraire? Trudno dziś na nie odpowiedzieć. Waluty, które raz zaczęły pełnić funkcję pieniądza międzynarodowego, pełnią ją na ogół bardzo długo, a utrata przez nie tego statusu jest zazwyczaj wynikiem długotrwałych i głębokich zaburzeń, prowadzących do zmian miejsc poszczególnych krajów w hierarchii politycznej i gospodarczej ${ }^{45}$.

Wydaje się, że czas SDR jako światowego numéraire jeszcze nie nadszedł. Trudno też przypuszczać, żeby status ten zyskała jakakolwiek inna jednostka. Nowe alokacje SDR otwierają jednak tej jednostce drogę do szerszego wykorzystania jako waluty rezerwowej. Mogą też stanowić zaczyn przyszłej dyskusji nad zakresem wykorzystywania tej jednostki. Będzie to jednak zależeć od stanowisk oraz interesów państw, które są głównymi „graczami” w międzynarodowych stosunkach walutowych. Niewątpliwie dziś zaliczają się do nich przede wszystkim USA i Chiny.

\section{ZAKOŃCZENIE}

Interesy USA i Chin dotyczące międzynarodowych stosunków walutowych do niedawna były sprzeczne. Chiny - dzięki utrzymywaniu podwartościowego

${ }^{42}$ The dollar's role...

${ }^{43}$ G. Dyer, China ready to take initiative on world economy, [w:] Deutsche Bundesbank, Auszüge aus Presseartikeln 2009, nr 15, s. 16.

${ }^{44}$ G. Dyer, op. cit., s. 16.

${ }^{45}$ J. Fels, The Composition of Central Bank Reserves: The Market Perspective, [w:] A. F. P. Bakker, R. Y. van Herpt (red.), Central Bank Reserve Management. New Trends, from Liquidity to Return, Edward Elgar, Cheltenham-Northampton 2007, s. 157. 
kursu juana wobec dolara - wspierały eksport, uzyskiwały znaczne nadwyżki w bilansach handlowych, co umożliwiało im gromadzenie oficjalnych rezerw walutowych ${ }^{46}$. Stany Zjednoczone natomiast, dążąc do zniwelowania nierównowagi $\mathrm{w}$ wymianie handlowej z Chinami, domagały się przeprowadzenia przez nie rewaluacji juana, zniesienia ograniczeń przepływów kapitału, a następnie dopuszczenia do większej elastyczności kursu chińskiej waluty ${ }^{47}$.

Światowy kryzys finansowy doprowadził jednak do zmiany stanowisk obu państw. USA, dostrzegając konieczność zwiększenia płynności międzynarodowej, przestały się sprzeciwiać nowym alokacjom SDR. Natomiast Chiny w większym stopniu są skłonne wziąć pod uwagę amerykańskie postulaty, dotyczące upłynnienia juana ${ }^{48}$. Dalsze utrzymywanie jego podwartościowego kursu i odwlekanie reform systemu kursowego wymaga bowiem coraz bardziej kosztownych interwencji walutowych ${ }^{49}$. Grozi również głębszym spadkiem wartości oficjalnych rezerw walutowych Chin wskutek aprecjacji juana, którą prędzej czy później trzeba będzie przeprowadzić.

Ten splot okoliczności może okazać się bardzo sprzyjający dla zmiany status quo jednostki SDR. Sprzyja bowiem nowemu spojrzeniu na zadania i zakres działań Międzynarodowego Funduszu Walutowego. Może się okazać, że efektem finalnym dyskusji w tej sprawie będzie odzyskanie przez jednostkę SDR statusu jednej z kilku głównych walut rezerwowych świata, jak to zakładano, dokonując jej pierwszych alokacji.

\section{THE CONCEPT OF INTERNATIONAL MONEY UNDER THE CIRCUMSTANCES OF THE GLOBAL FINANCIAL CRISIS}

SUMMARY

The purpose of this article is to analyze, whether and to what extent global financial turmoil, initiated with the U.S. subprime crisis, can provide a stimulus towards a creation of the new international money. A reduction of the dollar's share in the official foreign exchange reserves is considered to be a first step in order to achieve this goal.

${ }^{46}$ L. Lipschitz, C. Rochon, G. Verdier, The Domestic Solution. Can China's growth be sustained through good-neighbor policies?, „Finance \& Development” 2009, no. 1, s. 47-48.

${ }^{47}$ A. Persaud, The Politics and Micro-Economics of Global Imbalances, [w:] A. F. P. Bakker, R. Y. van Herpt (red.), op. cit., s. 37-39. Ten ostatni postulat Chiny w pewnym stopniu zrealizowały 21 lipca 2005 r., rozszerzając pasmo dopuszczalnych odchyleń kursu rynkowego juana wobec dolara na międzybankowym rynku walutowym spot z $0,3 \%$ na $0,5 \%$ (H. Xiaolian, China's $A p-$ proach to Reform, „Finance \& Development” 2007, no. 3, s. 37).

${ }^{48}$ L. Barber, M. Wolf, J. Anderlini, K. Hille, op. cit., s. 19.

${ }^{49}$ H. Sogano, Foreign Reserve Adequacy from the Asian Perspective, [w:] A. F. P. Bakker, R. Y. van Herpt (red.), op. cit., s. 71. 
The following issues are examined in the article: 1) the possibility of granting the unit of account of the IMF - SDR - the status of the main reserve currency; 2) the possibility of the fall of the dollar's share in the official foreign exchange reserves of the IMF's members in favor of other currency. Conducted research supports the view that these scenarios can become reality. However, this depends to the highest degree on the stand of the Asian countries on this matter. These very countries create very strong demand for American securities, helping keep the dollar dominant. 
